\title{
LAND ADMINISTRATION SYSTEM FOR SUSTAINABLE DEVELOPMENT - CASE STUDY OF POLAND
}

\author{
Agnieszka Dawidowicz, PhD \\ Faculty of Geodesy, Geospatial and Civil Engineering \\ University of Warmia and Mazury in Olsztyn \\ e-mail: dawidowiczagnieszka@wp.pl \\ Ryszard Źróbek, Prof., \\ Faculty of Geodesy, Geospatial and Civil Engineering \\ University of Warmia and Mazury in Olsztyn \\ e-mail:rzrobek@uwm.edu.pl
}

\begin{abstract}
The global idea of building state Land Administration Systems was to determine the infrastructures for the implementation of land policies and land management strategies in support of sustainable development. This new paradigm in science has directed many studies towards the development of concepts for the integration of various spatial information systems in the framework of interoperable infrastructures. Each infrastructure includes institutional arrangements, a legal framework, processes, standards, land information, management and dissemination systems, and technologies required to support allocation, land markets, valuation, control of use, and development of interests in land.

Many countries are in the process of developing Land Administration Systems (LAS). Databases of Land Information Systems (LIS), including cadastres, land registries, tax registries and land-use plans, are integrated to improve Land Information System functions and provide effective support for other systems and economic processes.

This article analyzes the LAS construction process in Poland with particular emphasis on the functionality of the infrastructure supporting the widely understood sustainable development of land, the economy and society. The presented solution may be an important model (template) for other national infrastructures.
\end{abstract}

Key words: Land Administration System, Sustainable Development, Cadastre.

JEL Classification: L85, Q01.

Citation: Dawidowicz A., Źróbek R., 2017, Land Administration System for Sustainable Development Case Study of Poland, Real Estate Management and Valuation, vol. 25, no. 1, pp. 112-122.

DOI: $10.1515 /$ remav-2017-0008.

\section{Introduction}

Land administration is not a new discipline. It has evolved out of the cadastre and land registration areas with their specific focus on the security of land rights (WILLIAMSON et al. 2010b). The global idea of building state Land Administration Systems (LAS) was to determine the infrastructures for the implementation of land policies and land management strategies in support of sustainable development. The term LAS is derived from the concept of Land Administration, which determines the processes of recording and disseminating information about the ownership, value and use of land and its associated resources when implementing land-management policies (UN, 1996; MOLEN, MISHRA, 2006). According to LEMMEN (2012) such processes include the determination of rights to land 
and other attributes of the land, the survey and description of these attributes, their detailed documentation and the provision of relevant information in support of land markets.

This new paradigm in science directed many studies towards the development of concepts for various land information systems integrated in the framework of interoperable infrastructures. Each infrastructure includes institutional arrangements, a legal framework, processes, standards, land information, management and dissemination systems, and technologies required to support allocation, land markets, valuation, control of use, and development of interests in land. All of these cannot function properly without an effective cadastral system.

There is an undeniable relationship between a Land Administration System and, e.g. land markets, the central economic driver for most countries (DALE, BALDWIN 2000). The phenomena observed on real estate markets indicate that the success of structural transformations and the development of property information systems are determined mainly by the quality and availability of information about real estate. The real estate market and LAS are bound by a feedback relationship (DAWIDOWICZ et al. 2014). The market supplies LAS with information about transactions and changes in property value, whereas LAS registers the supplied data, creates thematic databases and facilitates data processing. The effective operation of both systems and mutual interactions between the two influence decision-making processes. High-quality, reliable information contributes to the efficiency of decisions made on the real estate market.

Land administration theory requires the implementation of the land management paradigm to drive systems dealing with land rights, restrictions and responsibilities towards supporting sustainable development. The land management paradigm, where land tenure, value, use and development are considered holistically as essential and omnipresent functions performed by organized societies, is the cornerstone of modern land administration theory (WILLIAMSON et al. 2010b). The land management paradigm makes a national cadastre the engine of the entire LAS, underpinning the country's capacity to deliver sustainable development (Fig. 1). The cadaster should assist the functions of land tenure, land value, land use, and land development. In this way, within the LAS, the cadastre or cadastral system becomes the core technical engine delivering the capacity to control and manage land through the four LAS functions. They support business processes of tenure and value, depending on the built of the cadastre on a local scale (WILLIAMSON et al. 2010a).

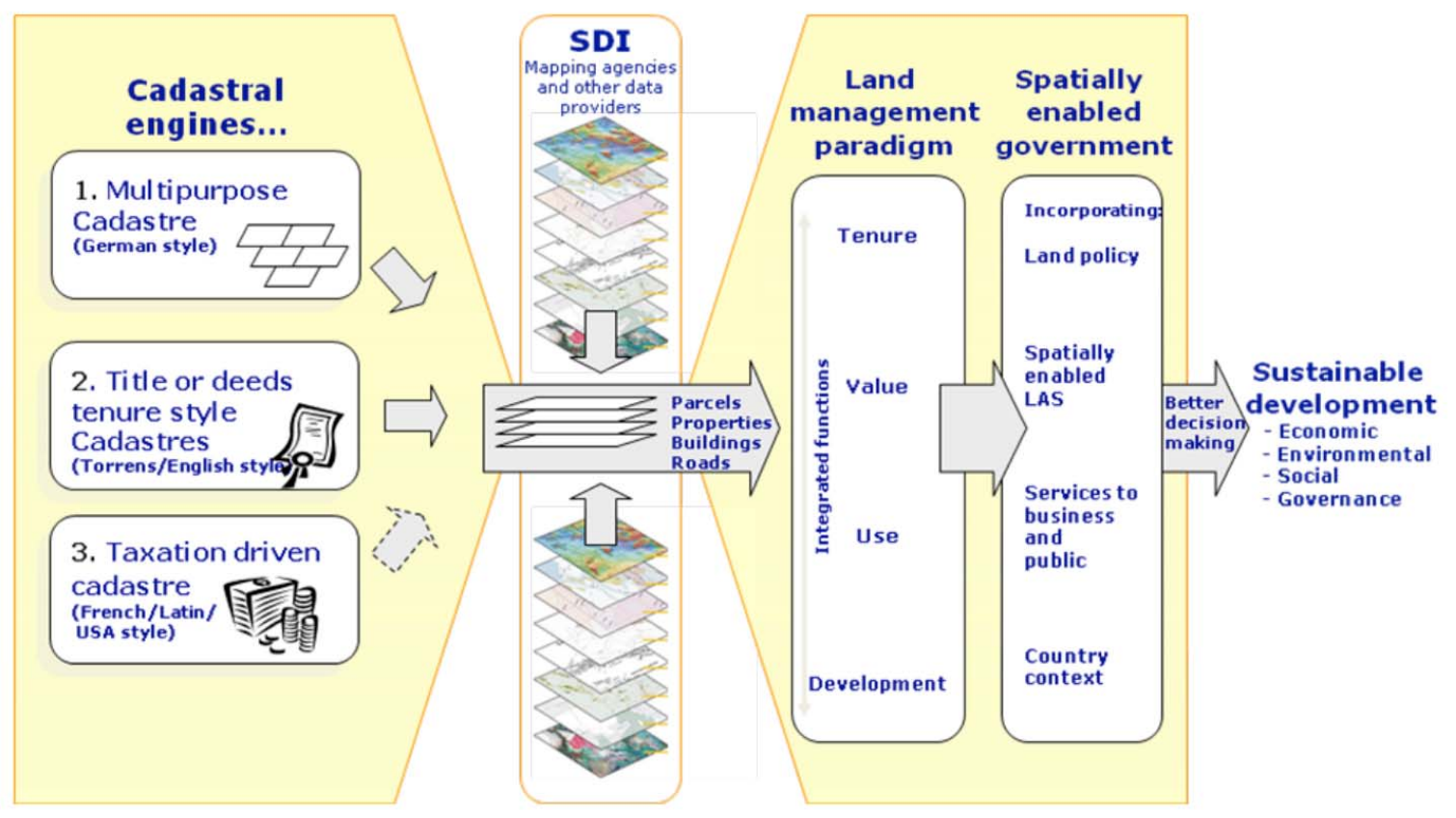

Fig. 1. The cadastre as an engine of LAS - the "butterfly" diagram. Source: Williamson et al. (2010).

Land management is broader than land administration. It covers all activities associated with the management of land and natural resources that are required to fulfill political objectives and achieve sustainable development. 
Land Administration Systems are a basic tool for the administration of natural resources, physical and economic planning, environmental monitoring and protection, and crisis management (LEMMEN, 2012). Using recent technology, LAS should deliver, to private and public sectors, complex information concerning the rights to land and limitations of such rights, supplying information which supports sustainable development (ENEMARK et al. 2005), (WILLIAMSON et al. 1999).

Many countries are in the process of developing Land Administration Systems. Databases of Land Information Systems (LIS), including cadastres, land registries, tax registries and land-use plans are integrated to improve Land Information System functions and provide effective support for other systems and economic processes contributing to the broadly understood concept of sustainable development.

After the Brundtland Commission (WCED, 1987; UN, 2007), sustainable development is understood as development that meets the needs of the present without compromising the ability of future generations to meet their own needs. It contains, within it, two key concepts:

- the concept of "needs", in particular the essential needs of the world's poor, to which overriding priority should be given, and

- the idea of limitations imposed by the state of technology and social organization on the ability of the environment to meet present and future needs.

A more recent and much more expansive definition can be found in the preamble to the ILA New Delhi Declaration (ILA, 2002): "the objective of sustainable development involves a comprehensive and integrated approach to economic, social and political processes, which aims at the sustainable use of natural resources of the Earth and the protection of the environment on which nature and human life as well as social and economic development depend and which seeks to realize the right of all human beings to an adequate living standard on the basis of their active, free and meaningful participation in development and in the fair distribution of benefits resulting there from, with due regard to the needs and interests of future generations". In brief, the importance of issues connected with sustainable development requires the engagement of all stakeholders in decision-making processes, as well as developing tactics and strategies (MANZHYNSKI et al. 2016).

LAS should support the sustainable policy moving towards achieving Millennium Development Goals - MDG (Fig.2), (UN, 2000) and new Sustainable Development Goals - SDG (Fig.3), (UN, 2015).

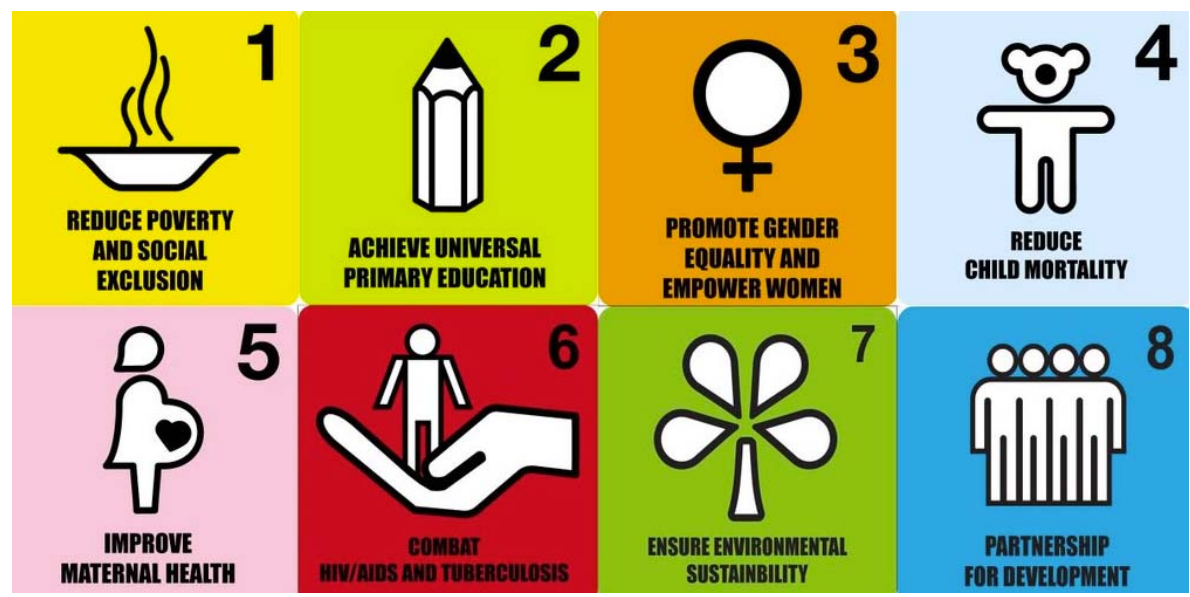

Fig. 2. Millennium Development Goals. Source: UN, 2000.

The new Agenda builds on the Millennium Development Goals (8) and seeks to complete what they did not achieve, particularly in reaching the most vulnerable. It goes far beyond the Millennium Development Goals. Alongside continuing development priorities, such as the eradication of poverty, health, education and food security, and nutrition, it sets out a wide range of economic, social and environmental objectives, as well as promising more peaceful and inclusive societies. Reflecting the integrated approach are deep interconnections and many cross-cutting elements ahead the new Sustainable Development Goals (17) and targets (169), (UN, 2015).

Considering these definitions, LAS should be developed informationally and technologically to assist sustainable development in the individual countries and throughout the world. With LAS, it will be possible to achieve social justice. 
This article analyzes the LAS construction process in Poland with particular emphasis on the functionality of the infrastructure supporting the widely understood sustainable development of land, economy, and society. The presented solution may be an important model (template) for other national infrastructures.
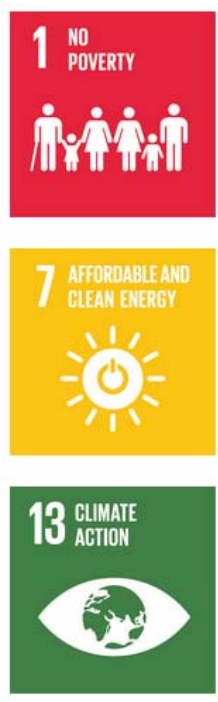
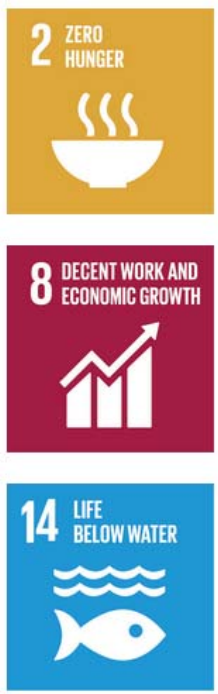
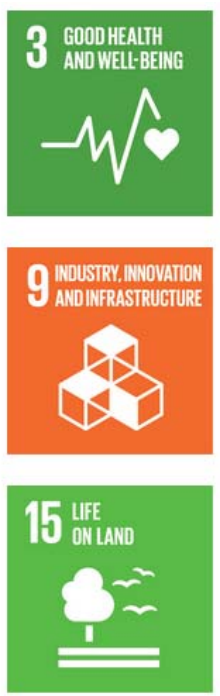
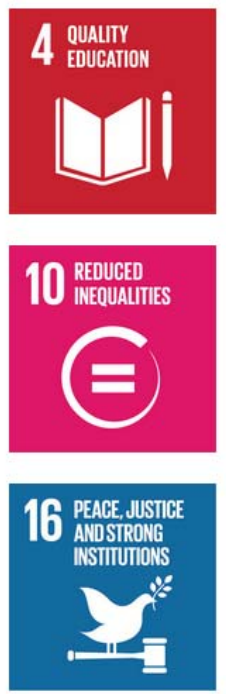
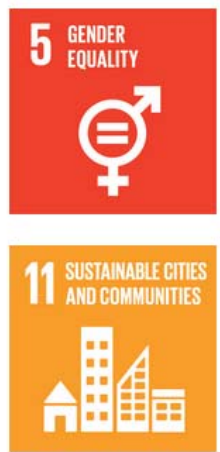

17 PARTNERSHIPS

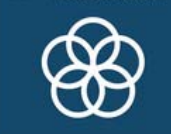

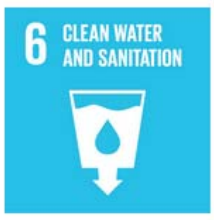

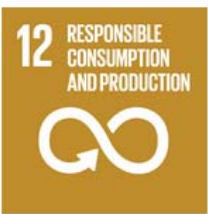

(4)

SUSTAINABLE DEVELOPMENT G.ALS

Fig. 3. Sustainable Development Goals. Source: UN, 2015.

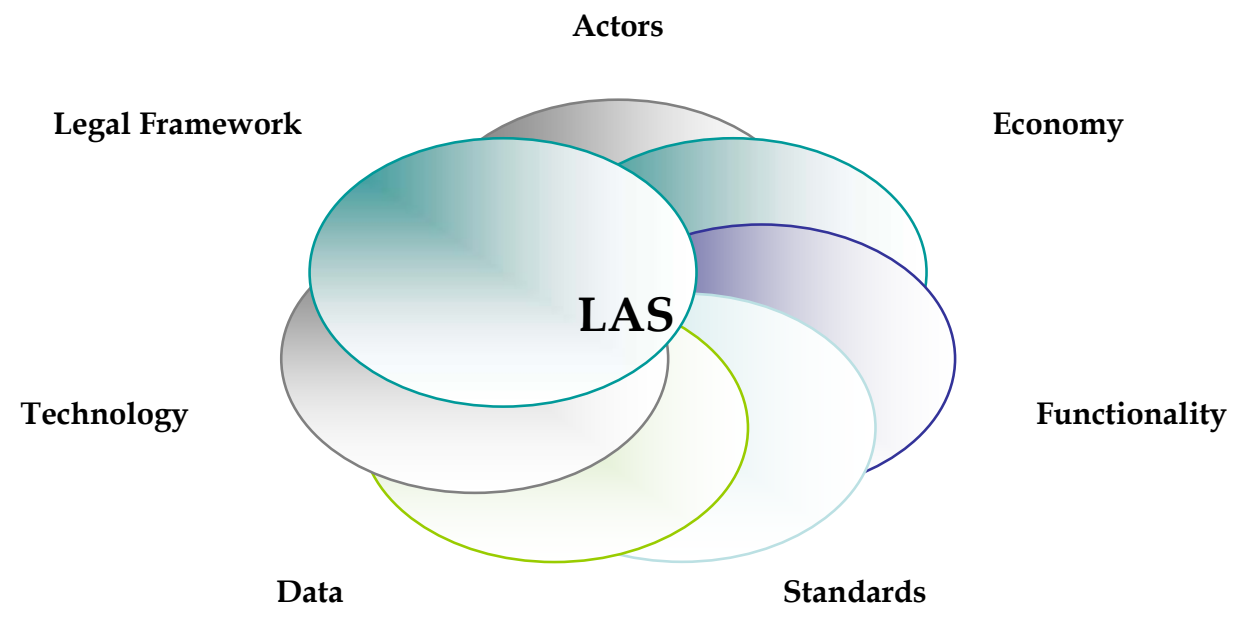

Fig. 4. Key elements of a Land Administration System. Source: own study.

\section{Data and Methods}

The main subject of the research is Polish Land Administration System. The research method was a case study based on an extensive analysis including a number of key issues outlined in the diagram shown below in Fig. 4. The proposed scheme results from the analysis of the concept of LAS and its definition, where Land Administration System means much more than just the ICT (Information and Communication Technology) component. A system can be described as a set of elements together with the relationships between the elements and between their attributes related to each other and to their environment so as to form a whole which aims to reach a certain goal (ZEVENBERGEN, 2002). 
The diagram directly follows from the definition of a Land Administration System created by WILLIAMSON et al. (2010), where a LAS should be understood as an infrastructure for the implementation of land policies and land management strategies in support of sustainable development. The infrastructure includes institutional arrangements, a legal framework, processes, standards, land information, management and dissemination systems, and technologies required to support allocation, land markets, valuation, control of use, and development of interests in land.

The adopted analytical method supplemented the diagnosis of all elements (legal framework, actors, economy, functionality, standards, data, technology) that determine the creation and functioning of Land Administration Systems. Thanks to this, a broad approach will be possible to identify Polish LAS conditions and development trends.

\section{Empirical results}

\subsection{Land Administration System in Poland - General assumptions}

Thanks to the development concepts of building strategic Land Administration Systems developed by FIG (1995, 1998, 2014) and UNECE (1996, 2005a, 2005b), WiLLIAMSON et al. (2010), the Polish government is redoubling its efforts to create a universal integrated land administration system in Poland. The concept of the government is to create a national LAS called the Integrated Real Estate Information System (IREIS), (Fig. 5), which will be a multi-purpose register available to public authorities and individuals. The basis for the creation of a national LAS is the Regulation of the Council of Ministers of 17 January 2013 on the Integrated Real Estate Information System. This innovative concept shows how land information systems in Poland have developed in relation to the situation described by DALE AND BALDWIN (2000).

The IREIS will functionally integrate the Real Estate Cadastre (Ewidencja Gruntów i Budynków EGiB), Land and Mortgage Register (Nowe Księgi Wieczyste - NKW), Tax System, Register of Economic Entities (Rejestr Gospodarki Narodowej - REGON), Population Register (Powszechny Elektroniczny System Ewidencji Ludności - PESEL), Official Register of the Territorial Administration Division (Krajowy Rejestr Urzędowego Podziału Terytorialnego Kraju TERYT), National Register of Producers and Agricultural Farms, and the Register of Applications Concerning Subsidies (Krajowy system ewidencji producentów, ewidencji gospodarstw rolnych oraz ewidencji wniosków o przyznanie płatności KSEP) as well as other public records through the functional specification of the Integrating Electronic Platform (IPE), which will allow the data to be viewed and transferred between a number of public registers. A diagram of IPE and IREIS system operations is presented in Figure 5.

In the IREIS project a central repository of cadastral data set copies will be created. The repository will be supplied with data from the county to conduct EGiB systems so that EGiB data of the whole country will be gathered in one place. In order to ensure consistency between registers that store data on real estate, the IREIS system will provide data exchange in the form of electronic documents between EGiB and other public registers such as NKW, PRG, TERYT, ID and KSEP. The task of the IREIS system will also include acting as intermediaries in transmitting notifications of changes to data made in the various public registers which are relevant to other public records included in the IREIS.

Basic, important information about the Polish LAS project can be found in the following Table 1.

\subsection{IREIS functionality}

IREIS will be based on the following functional assumptions (ADAMCZYK et al. 2014), (BUŚKO et al. 2014):

1) the exchange of data between the real estate cadastre and other public records will be in electronic form,

2) the tele-information system, used for the maintenance of the central repository, is to enable the recording, updating and safe maintenance of data files, and making them accessible in GML formats,

3) the applied software will enable the visualization of data and metadata, and for restoring the history of particular spatial object,

4) the software will enable automatic notifications of data changes in the cadastre,

5) access to data will take place over the Internet,

6) procedures for data conversion and cadastral database updates will be implemented by a set of applications, 
7) data integration will be carried by the Integrating Electronic Platform (IPE),

8) the data network will consist of LAN and WAN,

9) for the transformation of the source database of a real estate cadastre into a modern cadastral database, an application that will integrate the descriptive part and mapping will be installed,

10) the applied tele-information system will allow for performing analyses of data files, which should concern, in particular:

- preparing monthly reports with information on the number of buildings,

- performing statistical analyses concerning the utilization of data stored in registers which are included into the IREIS system,

- performing analyses of the coherence and quality of data files concerning the land and building registers,

- performing spatial analyses.

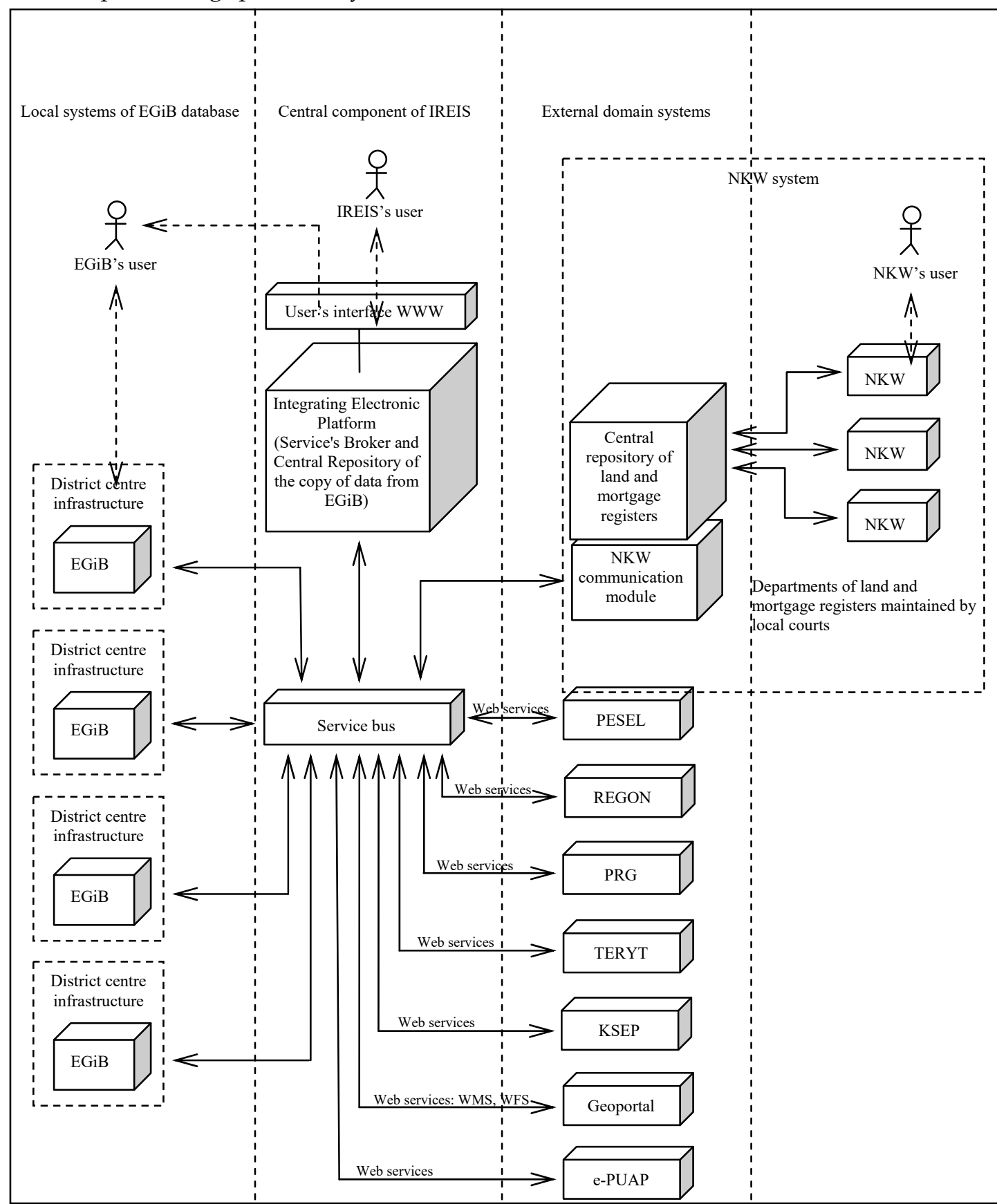

Fig. 5. Architecture of Polish Land Administration System (IREIS). Source: REGULATION, 2013. 
Table 1

Land Administration System in Poland - basic information

\begin{tabular}{|c|c|}
\hline Name of system & Integrated Real Estate Information System - IREIS \\
\hline Date of system conception & $1990-2000$ \\
\hline System startup & $\begin{array}{l}\text { Phase I - at the stage of records modernization, launched a pilot } \\
\text { (Gdańsk, Katowice, Kraków, Łódź, Poznań, Tychy) in } \\
\text { incomplete functional }\end{array}$ \\
\hline Financing & $\begin{array}{l}\text { Operational Programme Innovative Economy 2007-2013, in the } \\
\text { framework of priority axis } 7 \text { 'Information society - establishment } \\
\text { of electronic administration " }\end{array}$ \\
\hline Term of the project realization & 30 September 2015 \\
\hline Costs & 74 million PLN \\
\hline Data Storage Format & XML, GML 3.0 \\
\hline Legislation & $\begin{array}{l}\text { 1) ACT OF } 17 \text { MAY 1989. Geodetic and Cartographic Law, } \\
\text { (Journal of Laws of 2014, item. 897) } \\
\text { 2) Regulation of Council of Ministers of } 17 \text { January } 2013 \text { on the } \\
\text { Integrated Real Estate Information System. }\end{array}$ \\
\hline Technical Standards & ISO/TS 211 19100, Application Schema in UML \\
\hline $\begin{array}{l}\text { Ministry / organization } \\
\text { supervising the real estate } \\
\text { information system }\end{array}$ & $\begin{array}{l}\text { Ministers responsible for: public administration, internal affairs, } \\
\text { justice, public finances }\end{array}$ \\
\hline $\begin{array}{l}\text { Organization responsible for } \\
\text { maintaining the system at the } \\
\text { country level }\end{array}$ & $\begin{array}{l}\text { General Surveyor of Poland in cooperation with the province } \\
\text { governors and province marshals }\end{array}$ \\
\hline \multirow{9}{*}{ Integrated records } & Real Estate Cadastre \\
\hline & Land and Mortgage Register \\
\hline & TAX system \\
\hline & Topographic object database \\
\hline & GEOPORTAL \\
\hline & Population Register \\
\hline & Register of Economic Entities \\
\hline & $\begin{array}{l}\text { Register of Agricultural Producers, Farms and Requests for } \\
\text { payment }\end{array}$ \\
\hline & Open to connect with other systems \\
\hline
\end{tabular}

\section{Source: own study.}

As can be seen from the above description, the functionality of LAS in the future will fill a gap in the land information systems and flexibly adapt to the needs of users, in particular in the field of spatial analysis for the sustainable development of local municipalities. It seems very important that Spatial Data Infrastructures and LAS are moving into a second generation (HARVEY, TULLOCH, 2006), where the pyramid of data integration rests on local government data sharing.

\subsection{Towards sustainable development}

WILLIAMSON et al. (2010) selected key challenges or limitations that must be addressed if LAS are to achieve their full potential for supporting sustainable development. It becomes important to check what potential the current LAS in Poland presents. Table 2 presents the status of the Land Administration System in Poland in relation to the key challenges which a LAS should meet in order to support sustainable development.

The designed modern LAS in Poland, called the Integrated Real Estate Information System (IREIS), is developed based on global concepts and focused on sustainable development. Already at the stage of the first phase of project implementation it has met almost one hundred percent of the key challenges faced by a LAS. It is expected that the IREIS will provide comprehensive information and offer possibilities of their processing. The system will be well used and come closer to sustainable development. 
Land Administration System - key challenges

\begin{tabular}{|c|c|c|}
\hline $\begin{array}{c}\text { Key } \\
\text { challenges }\end{array}$ & LAS Desired States & $\begin{array}{c}\text { IREIS Project Status in } \\
\text { Poland }\end{array}$ \\
\hline
\end{tabular}

\begin{tabular}{ll}
\hline Land & Land governance means the spatial dimension \\
of governance & natural resources. It is the governmental side of \\
nand management. The control and \\
land phe the \\
management of physical space is the basis for \\
the distribution of power, wealth, opportunities \\
and human well-being. The key challenges of \\
the new millennium have already been clearly \\
listed in the international public arena. They \\
relate to climate change, food shortages, energy \\
scarcity, environmental degradation, and \\
natural disasters. These issues all relate to the \\
governance and management of land. Land \\
governance is a cross-cutting activity that must \\
be addressed holistically, thereby confronting \\
all traditional LAS.
\end{tabular}

\section{Urban \\ growth}

\begin{abstract}
Urban growth - According to UN-Habitat (UNHabitat, 2007), 2007 marked the year when the majority of the world's population now resides in urban areas distinct from rural areas, with urbanization continuing to increase. In parallel, the number of people living in poverty in urban slums facing very dangerous health and environmental conditions is increasing. Current LAS strategies have not been able to stabilize rural land sufficiently to slow this trend.
\end{abstract}

The new LAS tools must be developed to accommodate the urban growth.

Tools to Tools to administer the continuum of tenures administer While individual private rights will continue to the continuum of tenures be an important component of future LAS, the focus must change to new tools to administer the wide range of tenures that are being recognized from simply short-term occupation to full ownership. Administering a continuum of tenures and having tools that allow tenures to evolve over time are central to the next generation of LAS.

Tools to Tools to manage RRR - the concept of "land" is
manage RRR evolving. The unbundling of rights is occurring in formal systems to accord more with how informal or traditional systems work. At the same time, governments worldwide are accelerating their legislative and regulatory frameworks by creating legal restrictions and responsibilities on land to support sustainable development. In most developed countries, the number of statutes that have a spatial footprint and impose some restriction or responsibility on land has grown to unmanageable proportions. A common approach to managing
Aims of the IREIS project achieved
coincide with the aims of LAS
on Land governance as
follows:
1) Improving the process of
handling cases conducted
by the public
administration (The
development of public
services provided by
electronic means.
Ensuring communication
between public
administration systems).
Allowing citizens and
businesses direct online
access to reliable and
timely information about
the properties collected in
the public registers. IREIS allows monitoring and achieved viewing of population growth in urban areas through the integration of data from the Cadastre and Population Register.

$\begin{array}{ll}\text { The project IREIS does not } & \text { Partly } \\ \text { provide a complete set of tools } & \text { achieved }\end{array}$
to manage RRR. This would be possible if the register of local spatial development plans was included in the IREIS Project. 
these RRR used to rely on land title offices or land registries. However, today less than $1 \%$ of these RRR are managed by this approach. New and innovative LAS tools are required if these statutes and regulations are to have any chance of achieving their objectives.

\begin{tabular}{ll}
\hline LAS to & LAS to capitalise on technology - One of the major The IREIS Project is based on achieved \\
capitalise on & challenges for LAS worldwide is to "catch up the use of modern IT. \\
technology & with technology" or "capitalize on the promise It meets the needs of the \\
& of technology". There have been rapid government and the society \\
developments in spatial and GIS technologies sitting in the middle of the \\
over the last decade. However, most LAS have structures like e-Government \\
failed to capitalize on these opportunities. and SDI-Geoportal.gov.pl.
\end{tabular}
While the inability of current LAS tools and strategies to address urgent global issues is obvious, the power and promise of spatial technologies offer hope for the global poor. Modern LAS can play a key role in eGovernment and eDemocracy. Spatial technologies can break down historic institutional silos through data sharing and inter-operability within an SDI environment. Virtual jurisdictions, cities and societies offer exciting options and challenges. The power of location to revolutionize the way governments do business through spatial enablement is also opening up. Spatial technologies are at the heart of this new LAS evolution and a range of LAS tools is being developed.

Institutional Institutional catch up - LAS need to evolve to catch up reflect changes in the relationship between people and land. Unfortunately, one of the biggest limitations to capitalizing on the new and innovative tools offered by modern LAS to support sustainable development is the historic institutional arrangement of key agencies into separate silos. Still, today, in both the developed and developing world, the historic cadastral and LAS silos, and topographic and geographic information silos, continue to compete, stalling innovation and development. Only when the parcel layer is available can land information layers be efficient and effective. Efforts to rebuild road, property, and ownership layers outside registry and cadastral systems to give power to GIS are both fallible and expensive. If sustainable development is to be a reality, countries need to model and measure the impact of human activity (typically measured or evidenced by the cadastre) on the natural environment (usually represented by the national geographic information database or national mapping).

Spatial data are harmonized achieved
under the INSPIRE Directive
(2007) and the Land
Administration Guidelines
(UN-ECE 2005a, 2005b) and
ISO Standards for Land
Administration Domain
Model - LADM (ISO/TC211,
2012, BYDEOSZ 2013, 2015) in
order to create a basis for the
development and refinement
of effective LAS based on
MDA technology (Model
Driven Architecture) and
enable communication
between the interested parties
based on a common
vocabulary between
individual countries.

Source: own study based on WILLIAMSON et al. $2010 \mathrm{~b}$.

\section{Discussion and Conclusions}

In the context of the overall research methodology it can be concluded that the assumption of efficient LAS depends on many factors. First of all, it is important that all indicated key elements function properly. Therefore, a multidimensional approach is needed to create the system concept. It can be assumed that the trend of building LAS is a success due to favorable circumstances (transparent rules, an adequate legal framework, international standards, competent players, open financial projects and clear processes). 
The assumptions of an Integrated Real Estate Information System - IREIS (Polish Land Administration System) are in correlation with the key international concepts and standards to better land development support. IREIS are based on solutions developed by the FIG in 1989 - in the Cadastre 2014 paradigm to assist good governance. The Polish cadastre is progressively modernized. The developed cadastral model of presenting reality based on European ISO standards is in line with the guidelines of the Economic Commission for Europe (UN-ECE 1996) on Land Administration, under which Poland has been granted PHARE funds for the construction of an Integrated Cadastral System.

Plans to modernize the Polish real estate cadastre coincide with FIG plans for cadastre development towards supporting the Millennium Development Goals (UN, 2000) and New Sustainable Development Goals (UN, 2015).

The direction of the development of Polish LAS is consistent with the directions set out by the International Federation of Geodesy (FIG, 2012) and International Law Association (ILA, 2002).

\section{References}

ACT of 17 MAY 1989 Geodetic and Cartographic Law (in Polish: Prawo Geodezyjne i Karograficzne), (Journal of Laws of 2014, item. 897), www.isap.sejm.gov.pl.

AdamczyK T., Begović V., Bieda A., Bielecka E., Bugaj P., Dawidowicz A., Džunić I., Gajos M., JankowsKa M., Kereković D., KRUKowsKa K., KryszK H., Kurowska K., Parzych P., Rahmonov O., SCHRUNK I., WÓJCIAK E., ŹRÓBEK R., 2014, Spatial Data in Wide Geospace, Nacionalna knjižnica, Zagreb, p. 121.

BuŚKo M., BydŁosz J., DAwidowicz A., Gross M., Kwartnik-Pruc A., PietrZaK L., PrZEWiĘŹLIKowsKa A., TRZCiŃSKA S., ŹRÓBEK-RÓŻAŃSKA A., ŹRÓBEK R., 2014, Modern Systems of Land Administration and Real Estate Management, Nacionalna knjižnica, Zagreb, p. 86.

BYDŁOSZ J., 2015, The Application of the Land Administration Domain Model in Building a Country Profile for the Polish Cadastre, Land Use Policy 49 (2015), pp. 598-605.

BYDŁOSZ J., 2013, Polish Cadastral System and ISO 19152, Roczniki Geomatyki 2013, Vol. 11, Issue 2(59), pp. 15-23.

Dale P., Baldwin R., 2000, Lessons Learnt from the Emerging Land Markets in Central and Eastern Europe, Proceedings of FIG Working Week 2000, 21-26 May, Prague, pp. 1-32, http:/ / citeseerx.ist.psu.edu/viewdoc/download?doi=10.1.1.136.7356\&rep=rep1\&type=pdf (4.07.2016)

DAWIDOWICZ, A., RADZEWICZ A., RENIGIER-BIŁOZOR, M., 2014, Algorithm for Purposes of Determining Real Estate Markets Efficiency with Help of Land Administration System, Survey Review, Vol. 46, Issue 336 (May 2014), pp. 189-204.

ENEMARK S., WilliamsON, I., WAllace, J., 2005, Building Modern Land Administration Systems in Developed Economies, Journal of Spatial Science, 50(2) pp. 51-68.

FIG, 1995, FIG Statement on the Cadastre, FIG publication No 11, FIG Office, Copenhagen, http://www.fig.net/commission7/reports/cadastre/statement_on_cadastre.html (5.12.2010).

FIG, 1998, Cadastre 2014. A Vision for a Future Cadastral System. FIG publication No. 15, http://www.fig.net/cadastre2014/translation/c2014-english.pdf (22.02.2013).

FIG, 2012, Spatially Enabled Society, D. STEUDLER AND A. RAJABIFARD (Eds.) ISBN 978-87-90907-97-6, FIG Publication No. 58, Copenhagen, FIG Press, Denmark, p. 68.

FIG, 2014, Cadastre 2014 and Beyond, FIG publication No. 61, p.84, http://www.fig.net/pub/figpub/pub61/Figpub61.pdf (16.06.2014).

HaRveY F., Tulloch D., 2006, Local Government Data Sharing: Evaluating the Foundations of Spatial Data Infrastructures, International Journal of Geographical Information Science Vol. 20, Issue 7, pp. 743-768.

ILA, 2002, International Law Association (ILA) New Delhi Declaration on Principles of International Law relating to Sustainable Development, ILA resolution 3/2002, annex as published as UN Doc. A/57/329.

INSPIRE Directive, 2007, Directive 2007/2/WE of the European Parliament and Council, of March 14th 2007, establishing the infrastructure of Spatial Information in the European Community (INSPIRE) (OJ L 108, 25.4.2007, pp. 1-14).

ISO/TC211, 2012, Geographic Information - Land Administration Domain Model (LADM), ISO 19152. 
LEMmEN, CH., 2012, A Domain Model for Land Administration, NCG, KNAW, Delft, the Netherlands, $244 \mathrm{p}$.

MANZHYNSKI, S., SINIAK N., ŹRÓBEK-RÓŻAŃSKA A., ŹRÓBEK S, 2016. Sustainability Performance in the Baltic Sea Region. Land Use Policy, Vol. 57, 30 November 2016, pp. 489-498.

MOlen VAN DER P., MishrA S., 2006, Land Administration and Social Development. Enhancing Land Registration and Cadastre. GIM International, Mapping the world. http://www.giminternational.com/content/article/land-administration-and-social-development (4.07.2016).

REGUlATION, 2013, Regulation of Council of Ministers of 17 January 2013 on the Integrated Real Estate Information System (Journal of Laws, item 249), (in Polish: Rozporządzenie Rady Misnistrów z dnia 17 stycznia 2013 r. w sprawie zintegrowanego systemu informacji o nieruchomościach), Dz. U. z dnia 22 lutego 2013 r. (Journal of Laws of 22 February 2013), www.isap.sejm.gov.pl.

UN, 2000, United Nations Millennium Declaration, Resolution 55/2. https://documents-ddsny.un.org/doc/UNDOC/GEN/N00/559/51/PDF/N0055951.pdf?OpenElement (5.04.2016).

UN, 2007, Framing Sustainable Development. The Brundtland Report - 20 Years On. http://www.un.org/esa/sustdev/csd/csd15/media/backgrounder_brundtland.pdf (30.03.2016).

UN, 2015, Transforming our world: the 2030 Agenda for Sustainable Development. UE Sustainable Development Agenda, Resolution A/RES/70/1, pp. 35, http:/ / www.un.org/ga/search/view_doc.asp?symbol=A/RES/70/1\&Lang=E (1.07.2016)

UN-ECE, 1996, Land Administration Guidelines, UNECE, Geneva, pp. 112. http://www.unece.org/env/hs/wpla/docs/guidelines/lag.html (08.04.2014).

UN-ECE, 2005a, Guidelines on Real Property Units and Identifiers. Geneva, p. 80, available at: http://www.unece.org/fileadmin/DAM/env/documents/2005/wpla/Guidelines_On_Real_Prop erty_Identifiers.pdf (29.06.2016).

UN-ECE, 2005b, Land Administration in the UNECE Region. Development Trends and Main Principles, Geneva 2005 http:/ / www.unece.org/fileadmin/DAM/env/documents/2005/wpla/ECE-HBP-140-e.pdf (29.06.2016).

UN-HABITAT, 2007, Global Report on Human Settlements 2007 - Enhancing Urban Safety and Security. pp. 448.

WCED, 1987, World Commission on Environment and Development, Our Common Future, Oxford, Oxford University Press, 1987, pp. 43.

Willamson, I. P., TING, L., GRANT, D., 1999, The Evolving Role of Land Administration in Support of Sustainable Development, Australian Surveyor, 44(2) pp. 126-135.

Williamson, I.P, ENEMARK, S., WALLACE, J., RAJABIFARD, A., 2010a, Land Administration for Sustainable Development, ISBN 978-1-58948-041-4, ESRI Press, p. 487.

WilLIAMSON, I.P, ENEMARK, S., WALLACE, J., RAJABIFARD, A., 2010b, Land Administration for Sustainable Development, FIG Congress 2010 Facing the Challenges - Building the Capacity, Sydney, Australia, 11-16 April 2010.

Zevenbergen, J.A., 2002, Systems of Land Registration. Aspects and Effects, PhD thesis. Geodesy. Delft, The Netherlands, Delft University of Technology, p. 210. 